Teologia i Moralność, Volumen 15(2020), numer 2(28)

doi: 10.14746/tim.2020.28.2.12

ORCID: 0000-0002-0894-7747

NATASZA DOICZMAN-ŁOBODA

Uniwersytet im. Adama Mickiewicza w Poznaniu

Wydział Socjologii

\title{
Problem „eurosieroctwa” w opinii ekspertów kierujących pomoc do rodzin migrantów zarobkowych. Praca socjalna i wsparcie psychologiczne w doświadczeniach rozląki migracyjnej
}

Termin „eurosieroctwo” w literaturze przedmiotu wyjaśniany jest w bardzo różnorodny sposób, między innymi przez położenie nacisku na kwestię sieroctwa społecznego i wyliczenie zwykle negatywnych konsekwencji rozłąki. Podejmowane są próby obiektywizacji terminu, a nawet tworzenia łagodniejszych określeń opisujących sytuację pozostawania dzieci migrantów w kraju pochodzenia bez opieki rodzica. W prezentowanym artykule „eurosieroctwo" traktuję jako odczuwany przez dziecko brak rodzica/rodziców wynikający z zagranicznej migracji zarobkowej jednego bądź obojga rodziców, mającej miejsce po wstąpieniu Polski do Unii Europejskiej (dalej UE). Termin ten wiążę bezpośrednio $\mathrm{z}$ doświadczeniami piętna i stygmatyzacji wytwarzanymi przez „społeczną widownię”. Więź łącząca członków rodziny z migrantem jest zagrożona, mimo że komunikacja podczas rozłąki migracyjnej przebiega sprawnie. Wyjazd rodziców prowadzi do szybkiego usamodzielnienia się dzieci i skrócenia okresu oddziaływania rodziny na życie jednostki. Młodzież poszukująca treści dla rozwoju swojej tożsamości musi korzystać z materiału innych środowisk, ponieważ oddziaływania biografii oraz tradycji rodzinnej są w sytuacji rozłąki migracji ograniczone. Czas dorastania jest okresem, w którym kształtuje się rozwój i rozumienie własnej biografii, wobec tego na tym etapie wspólnotowy charakter rodziny ma szczególne znaczenie. Niniejszy artykuł prezentuje wyniki badań prowadzonych wśród ekspertów: pracowników socjalnych, psychoterapeutów, psychologów i pedagogów szkolnych, kuratorów, którzy w ostatnich dwóch latach kierowali ofertę pomocową do rodzin migracyjnych, w tym dzieci i młodzieży doświadczającej „eurosieroctwa”. 


\section{Migracje zarobkowe wśród Polaków}

Od roku 2004 można zauważyć intensywny wzrost zainteresowania losami rodzin migrantów oraz burzliwą debatę nad skutkami rozłąki z rodziną, która ma odzwierciedlenie między innymi w literaturze naukowej, popularnej, a szczególnie w mediach. Obserwuje się także ciągły wzrost rozwoju badań nad migracjami oraz rosnące zapotrzebowanie na różnego rodzaju dane oraz analizy dotyczące migracji z perspektywy interdyscyplinarnej (Horolets, Lesińska, Okólski 2019). Zainteresowanie problematyką funkcjonowania rodzin rozłączonych przestrzennie wynika $\mathrm{z}$ aktualności problemu migracji zarobkowych, które skutkują różnego rodzaju konsekwencjami w funkcjonowaniu rodziny migracyjnej (Kawczyńska-Butrym 2009). Polska od dziesięcioleci cechuje się wysokim stopniem migracyjności (Kaczmarczyk, Okólski 2008). Wstąpienie Polski do UE wiązało się z rozpoczęciem fali migracji, nazywanych poakcesyjnymi, kiedy wiele europejskich krajów dało Polakom możliwość pracy zarobkowej. Joanna Kozielska wskazuje, że „Dzień 1 maja 2004 roku stał się znamienną datą, oznaczającą zniesienie wielu barier i granic, zarówno w dosłownym, jak i przenośnym znaczeniu tych słów" $(2014,75)$. Za istotną przyczynę migracji Polaków uznaje się złą sytuację finansową i wyższe zarobki za granicą (Chmielewska, Panuciak, Strzelecki 2019). Częstym celem migracji jest zapewnienie bezpieczeństwa socjalnego rodzinie, nawet kosztem jakości własnego życia w społeczeństwie przyjmującym (Krzyżowski, Mucha 2012). W Polsce większość emigracji rodziców pozostawiających dzieci w kraju to migracje krótkoterminowe, często o sezonowym charakterze (Walczak 2008).

W roku 2018 poza granicami Polski przebywało około 2455000 osób (GUS 2019). Najwięcej Polaków migruje do: Niemiec, Wielkiej Brytanii, Holandii, Irlandii, Włoch i Norwegii. Warto zwrócić uwagę na to, że skala emigracji Polaków za granicę nadal jest wysoka, ale jej wzrost nie jest już tak dynamiczny jak latach ubiegłych. Społeczeństwo polskie odznacza się bardzo długą historią mobilności. Polska była określana dotąd mianem kraju emigracji, co oznacza, że liczniejsze były wyjazdy Polaków za granicę niż imigracja cudzoziemców do Polski (Kaczmarczyk, Tyrowicz 2007). Aktualnie dobra sytuacja na polskim rynku pracy ograniczyła powiększanie się liczby emigrantów, chociaż nadal obserwuje się ujemne saldo migracji z Polski (Chmielewska i in. 2019). Jak wskazuje Główny Urząd Statystyczny (2019), można przypuszczać, że większość Polaków, która wyjechała za granicę do pracy po wstąpieniu Polski do UE, została tam do chwili obecnej.

Funkcjonowanie Polaków na zagranicznym rynku pracy znacząco nie zmienia się od lat. Emigranci zarobkowi wciąż podejmują prace mniej prestiżowe i gorzej opłacane niż rodzimi mieszkańcy krajów przyjmujących. De- 
cydują się na zajęcia, które nie wymagają dobrej znajomości języka obcego, głównie wybierając zatrudnienie w hotelarstwie, budownictwie, gastronomii, przemyśle, przy prostych pracach biurowych (Duszczyk, Wiśniewski 2007). W związku z tym w literaturze pojawia się termin tzw. „marnotrawienia mózgów" (ang. brain waste) oznaczający sytuację pracy poniżej kwalifikacji, z jednej strony identyfikowaną jako popularną wśród Polaków, z drugiej trudną do oszacowania (Baranowski, Gądek, Stelmasiak, Wójcik 2016). Od lat dziewięćdziesiątych XX wieku wyjazd z kraju w celach zarobkowych przestał być rozpatrywany w kategoriach sukcesu (Galasińska, Horolets 2010). Emigracja uwarunkowana kwestiami ekonomicznymi jest coraz częściej uznawana za przejaw bezradności i braku umiejętności znajdowania rozwiązań powodujących poprawę sytuacji materialnej rodziny. Często decyzje o migracji podejmowane były spontanicznie, bez namysłu, bilansu zysków i strat, a także bez konsultacji z osobami, które mogą kierować ofertę pomocową do rodzin rozważających wyjazd zarobkowy.

\section{Podstawy badań wlasnych}

Do udziału w badaniu zaproszono grupę ekspercką składającą się z dziewięciu przedstawicieli zawodów pomocowych związanych z udzielaniem wsparcia rodzinom doświadczającym rozłąki migracyjnej. Prezentowane w niniejszym artykule badania stanowiły jeden z elementów zdecydowanie większego projektu, który zakładał uzyskanie wielowątkowego, syntetycznego, a zarazem szerokiego portretu współczesnej rodziny migracyjnej, dzięki przeprowadzeniu autobiograficznych wywiadów narracyjnych, wywiadów kwestionariuszowych, a także wywiadów swobodnych z dziećmi migrantów zarobkowych oraz pozostałymi członkami rodzin migracyjnych ( $\mathrm{tj}$. rodzicami migrantami, rodzicem pozostającym w kraju pochodzenia z dziećmi, babciami, ciociami oraz rodzeństwem głównych narratorów). W przypadku rodzin migracyjnych, z którymi odbywała się współpraca, musiał być spełniony warunek wyjazdów poakcesyjnych praktykowanych przez rodziców, co oznaczało, że wyjazdy rodziców migrantów odbywały się do państw członkowskich UE, a ich intensywność znacznie zwiększyła się po wstąpieniu Polski do UE. W podjętych badaniach dobór próby miał charakter celowy. Został zaplanowany ze względu na jakościowy charakter prowadzonych badań. Prowadzone były wywiady swobodne z psychoterapeutą, psychologami i pedagogami szkolnymi, pracownikami socjalnymi, kuratorami, którzy w ostatnich dwóch latach kierowali ofertę pomocową do rodzin migracyjnych. Badania odbywały się w województwie wielkopolskim, kujawsko-pomorskim, lubuskim, opolskim i śląskim. Wybór terenu badań opierał się na występowaniu poakcesyjnej 
emigracji zarobkowej o szerokiej skali i wysokiej stopy bezrobocia na tych obszarach. W badaniu wzięli udział zarówno mieszkańcy wsi, jak i miast do 20000 mieszkańców, rzadziej do 100000 mieszkańców. Jednak warto zaznaczyć, że rozmieszczenie geograficzne doświadczeń „eurosieroctwa” nie było kluczowe w realizowanym projekcie badawczym. Obserwowane przez badanych doświadczenia rozłąki w niniejszym artykule nie są zatem porównywane pod względem województw o różnym natężeniu emigracji. Bez względu na rozmieszczenie przestrzenne rozłąka z rodzicami, rytm życia rodzin migracyjnych i stygmat „eurosieroctwa” są podobnie doświadczane i interpretowane przez dzieci emigrantów. Podczas wywiadów swobodnych ze standaryzowaną listą poszukiwanych informacji, przeprowadzanych z ekspertami, wykorzystałam listę dyspozycji zawierających m.in. kwestie dotyczące:

- wyzwań, przed którymi stoi szkoła wobec dziecka, którego rodzice wyjechali z kraju,

- liczby dzieci emigrantów, do których kierowana była przez respondentów oferta pomocowa,

- szczegółów dotyczących współpracy z rodziną migracyjną,

- zauważanych skutków rozłąki,

- etykiety „eurosierota”,

- sposobu postrzegania problematyki rodzin migracyjnych,

- kwestii codziennego funkcjonowania dzieci emigrantów zarobkowych,

- sprawowania bezpośredniej pieczy nad dziećmi emigrantów,

- pozytywnych i negatywnych przejawów skutków nieobecności rodziców,

- prowadzonych oddziaływań wobec rodzin migracyjnych, podejmowania tematu rozłąki migracyjnej podczas rozmów ze współpracownikami,

- zebrań, szkoleń oraz poczucia przygotowania ich do działania jako osób wspomagających pracę z członkami rodzin migracyjnych.

Zdaniem respondentów, problematyka funkcjonowania rodzin migracyjnych, a szczególnie dzieci emigrantów, jest bardzo ważna, a często niedostrzegana w ich pracy. Zofia Kawczyńska-Butrym i Marzena Kruk zauważają, że „Przegląd literatury przedmiotu i dotychczasowych badań wskazuje na kilka elementów systemu społecznego, które mają istotne znaczenie w niesieniu pomocy rodzinom i dzieciom rodzin migracyjnych. Autorzy wymieniają wśród nich szkołę (jako podstawowy i główny podmiot wsparcia), pomoc pedagogiczno-psychologiczną, pomoc społeczną, kuratorów sądowych, Kościół" (2015, 212). Przeprowadzone przeze mnie badania wskazują, że szczególnie pedagodzy i psycholodzy szkolni zauważają szereg trudności pojawiających się w związku z dorastaniem uczniów w rodzinach migracyjnych. 


\section{Praca z rodziną migracyjną w opinii ekspertów}

Psycholodzy szczególnie często obserwują różnorodne trudności emocjonalne dziecka (inne w zależności od wieku), które wychowuje się w rodzinie migracyjnej i tym samym często pozostaje pod opieką jednego rodzica. Badani jednomyślnie zgadzali się, że postawa nauczyciela, wychowawcy, a także pracowników zespołu psychologiczno-pedagogicznego jest w tej sytuacji bardzo istotna. Konieczność uzyskania pisemnych zgód opiekuna prawnego w związku z wyjazdem dziecka na wycieczkę lub skierowaniem ucznia do odpowiedniej poradni, to tylko niektóre formalne problemy, jakie wymieniali eksperci. Nieuchronną sytuacją jest także współpraca z obojgiem rodziców przy okazji omawiania codziennych problemów edukacyjnych, która właśnie ze względu na długotrwałą nieobecność rodzica jest znacznie utrudniona a czasem niemożliwa.

Nie wszystkie szkoły ze względu na brak psychologów szkolnych mają możliwość objęcia dziecka, tym bardziej całego systemu rodzinnego, opieką, a także udzielenia wsparcia na wielu płaszczyznach, choćby w zakresie poznawczym, instrumentalnym oraz, co najważniejsze, emocjonalnym. Istotne jest to, że eksperci na przestrzeni kilku lat zauważali zmianę związaną z bardzo dużą chęcią współpracy rodzin w tym obszarze. Psycholodzy w swojej pracy spotykają matki, które często korzystają z możliwości opowiedzenia o swoich trudnościach i odreagowania napięć, związanych głównie z samotnością i przeciążeniem obowiązkami, trudnościami emocjonalnymi w związ$\mathrm{ku} \mathrm{z}$ reorganizacją życia rodzinnego na czas powrotów migranta. $\mathrm{Z}$ ich doświadczeń wynika, że matki, przychodząc na spotkanie w sprawie dziecka/ /ucznia, same przyznają, że to one mierzą się z licznymi trudnościami emocjonalnymi i potrzebują wsparcia psychologa. Wspólnie z dziećmi czasami korzystają z sugestii dotyczących nowych form kontaktu z nieobecnym członkiem rodziny.

Psycholodzy i pedagodzy we współpracy z wychowawcami poszukują rozwiązań trudności emocjonalnych i zaburzeń zachowania dzieci w tej szczególnej sytuacji, spotykają się, aby monitorować efekty pomocy. Z obserwacji psychologa szkolnego wynika, że wiedza na temat trudnej sytuacji emocjonalnej dziecka sprawia, iż nauczyciel łagodniej ocenia jego zachowanie. Respondenci w swojej pracy zawodowej spotykali się z dziećmi, których zarówno oboje rodzice, jak i jeden z nich pracował za granicą. Najczęstszą sytuacją była jednak ta, w której to ojciec podejmował pracę zarobkową poza granicami kraju, a w kraju pochodzenia razem $\mathrm{z}$ dziećmi pozostawała matka. Brak poczucia równowagi $\mathrm{w}$ rodzinie, zawieszenie między sytuacją obecności a nieobecności rodzica sprawiały, że sytuacja dzieci była w takich rodzinach szczególnie złożona. Bezpośrednią pieczę nad dziećmi w sytuacji emi- 
gracji rodzica przeważnie sprawowali: matka, babcia i dziadek, ale zdarzało się, że niepełnoletnim dzieckiem opiekowało się rodzeństwo. Badani eksperci najczęściej od nauczycieli dowiadywali się, że rodzice dziecka przebywają na emigracji zarobkowej, a następnie od dziecka, z którym współpracowali. We wszystkich znanych respondentom przypadkach dzieci przejawiały jakiś rodzaj trudności: relacyjne, zachowania agresywne, obniżony nastrój i/lub płaczliwość, lękliwość itp., co zwracało uwagę przede wszystkim nauczycieli, którzy do nich zwracali się o pomoc. Kolejnym krokiem najczęściej było zaproszenie do współpracy rodzica, pod którego opieką pozostaje dziecko.

Zdaniem ekspertów, dziecko wychowujące się w rodzinie migracyjnej przede wszystkim zmaga się z permanentną tęsknotą za rodzicem. Często nie rozumie powodów, dla których ten wyjechał, i postrzega to jako „opuszczenie" (E.5; E. $\left.8^{1}\right)$. Uczestnicy badań opowiadali o tym, że znane są im przypadki dzieci, które nieświadomie dążą do uzyskania negatywnej uwagi, ponieważ sytuacja, w której muszą ponieść przykre konsekwencje, nie umknie uwadze pozostającego poza domem rodzica. Tym samym dziecko zdobywa pewność, że rodzic z nim porozmawia, zainteresuje się jego problemem czy nawet udzieli upomnienia - to także jest rodzaj kontaktu, za którym tęskni dziecko. Cechą charakterystyczną wywiadów z ekspertami jest fakt, że podawali oni wiele przykładów ze swojej pracy zawodowej. (Jedna z badanych [E.9] za szczególną uznała sytuację dziewczyny, która po dłuższej nieobecności ojca zaczęła kraść drobne przedmioty. Ojciec nawiązywał kontakt głównie z matką dziewczyny - to od niej pozyskiwał informacje na temat dzieci. Problem ustał w momencie, kiedy ojciec bardziej zaangażował się w wychowanie córki, choć wciąż przebywał na emigracji). Także na podstawie danych Obserwatorium Integracji Społecznej ROPS w Opolu można wywnioskować, że wśród problemów społecznych dotykających dzieci emigrantów zarobkowych na pierwszym miejscu rodzice wskazują chęć zwrócenia na siebie uwagi (Goleński 2016).

Zdaniem ekspertów, w zależności od typu relacji z rodzicami, komunikacji w rodzinie, ale także osobowości samego dziecka, żal wobec wyjeżdżającego rodzica może się przerodzić w złość i/lub wykorzystywanie sytuacji dla osiągnięcia własnych korzyści. Badani zwracali uwagę na sytuacje, w których dzieci antagonizują rodziców, przeciwstawiają ich decyzje, niejako podejmując zachowania manipulacyjne, np. dzwonią do rodzica, który przebywa na emigracji, i żalą się na sytuację $\mathrm{w}$ domu oraz decyzje drugiego rodzica, poszukując u niego wsparcia. Wskazywali, że młodzież głównie oczekuje zadośćuczynienia za okres nieobecności.

Innym problemem jest to, że dorastające dziecko generalnie ma poczucie braku zrozumienia ze strony dorosłych, co znacznie nasila nieobecność rodzi-

\footnotetext{
${ }^{1}$ Oznaczenia respondentów.
} 
ca w życiu codziennym rodziny. Respondenci przytaczali wypowiedzi nastolatków: „ojciec przyjechał i zaczyna się rządzić” (E.9), „on nic o nas nie wie” (E.7), które także pojawiały się w prowadzonych przeze mnie wywiadach. W swojej pracy zawodowej eksperci spotykali się z sytuacjami, w których wyczekiwane powroty przebywających daleko od domu rodziców często kończyły się kłótniami, wzajemnymi oskarżeniami i pogłębieniem niechęci. Zgodnie z wynikami prowadzonych przeze mnie badań psycholodzy, pedagodzy i pracownicy socjalni uważają, że rodzina adaptuje się do sytuacji nieobecności, więc w związku z tym powrót migranta, jakkolwiek oczekiwany, burzy ład i wymaga ponownego dostosowania się do zmieniających się okoliczności. Powracający emigrant spodziewa się, że zastanie znany sobie porządek i sposób funkcjonowania rodziny. Emigrant mierzy się z rozczarowaniem, gdy rzeczywistość okazuje się inna, w związku z czym wszyscy mają poczucie odrealnienia, wyobcowania i niezaspokojenia. Zdaniem ekspertów pracujących z młodzieżą z rodzin migracyjnych w szkołach, gdy nastolatek, którego rodzice przebywają na emigracji zarobkowej, odczuwa tęsknotę za rodzicem, odrzucenie, samotność, brak zrozumienia, często ucieka w wirtualny świat. „Świat gier, portali społecznościowych itp. pozwala na ucieczkę i na zapomnienie. Wirtualna komunikacja - bez ograniczeń - jest dla niego lekarstwem na złudne poczucie komfortu psychicznego" (E.2).

Uczestnicy badań pytani o przejawy negatywnych skutków nieobecności rodziców, z jakimi spotkali się w swojej pracy, najczęściej wymieniali zaniedbania w nauce, stany depresyjne, pogorszenie relacji z rówieśnikami, agresję, absencję szkolną oraz uzależnienia od komputera i telefonu. Zdaniem ekspertów, rodzice chętnie współpracują i rozumieją problemy swoich dzieci. Należy im pomóc w poprawieniu komunikacji w rodzinie. „Aktywne słuchanie czy komunikaty typu ja, to tak naprawdę drobne zmiany, które mogą przynieść pozytywne rezultaty. Ważne, aby podkreślać, że dystans w sensie odległości mierzonej w kilometrach nie musi iść w parze z dystansem emocjonalnym" (E.9).

Psycholodzy podkreślali, że dzieci emigrantów wyrażają ogromną tęsknotę za rodzicem, który pracuje z dala od domu, oraz ujawniają również, często nieuświadomioną, złość na sytuację, w której znajduje się rodzina. Zdaniem respondentów, młodzież przejawia negatywny stosunek do wyjazdów swoich rodziców. Eksperci opisywali obserwowaną przez nią pozorowaną obojętność, która była wyrażana w słowach: „niech jedzie”, „niech wraca do siebie" (E.3), racjonalizowanie (poszukiwanie argumentów za) oraz narastające wraz z upływem czasu poczucie osamotnienia i niezgodę na taki stan rzeczy. W swojej pracy badani często spotykają się z powtarzanymi przez młodzież przekonaniami, że „rodzina powinna być razem” (E.1; E.4; E.6; E.9), co potwierdzają także wypowiedzi młodzieży w prowadzonych przeze mnie badaniach. Eksperci podkreślali także sprzeczności w rozumieniu doświad- 
czeń rozłąki emigracyjnej przez dzieci emigrantów. Z jednej strony młodzież $\mathrm{z}$ rodzin migracyjnych rozumie, że rodzice wyjeżdżają za granicę dla dobra całej rodziny, chcąc poprawić sytuację materialną, np. spłacić kredyty, wyremontować dom, z drugiej mówi jednak o destruktywnym wpływie rozłąki na relacje łączące członków rodziny i wymienia szereg negatywnych konsekwencji w związku z migracją.

Zdaniem respondentów, przede wszystkim należałoby podjąć działania pomocowe dotyczące emocji młodzieży, nawet jeśli sytuacja jest dla nich akceptowalna czy zrozumiała poznawczo, aby zmniejszyć nasilenie negatywnych skutków emigracji zarobkowej. Według wielu ekspertów problemem jest to, że „W rodzinach poświęca się dużo czasu na mówienie o faktach. Dzieci są wyłączone z procesu decyzyjnego rodziców” (E.1). Badani podkreślali, jak ważne jest, by włączać dziecko w proces podejmowania decyzji i planowania przyszłości związanej $\mathrm{z}$ doświadczeniami rozłąki, wspólnie poszukiwać rozwiązań, pytać o potrzeby dziecka, dać mu możliwość wyrażenia ich tak, by jego uczucia mogły zostać usłyszane i stały się przedmiotem rozmowy. Psycholodzy podkreślali, że komunikowanie decyzji oraz pozostawienie dziecka z kategorycznym stwierdzeniem, że „tak musi być”, utrudnia radzenie sobie $\mathrm{z}$ rozłąką. Respondenci sugerowali, że warto zmianę w życiu całej rodziny przeprowadzać z dodatkowym wsparciem specjalisty (m.in. psychologa, pracownika socjalnego, asystenta rodziny). W wywiadach eksperckich często poruszana była kwestia przeciążenia pozostających w kraju pochodzenia członków rodziny. Respondenci podkreślali, że fizyczna rozłąka nie powinna wiązać się z nieobecnością emocjonalną oraz przejmowaniem wszystkich zadań drugiego rodzica przez pozostających w domu członków rodziny. ,Jednoczesne podejmowanie ról obojga rodziców przez jedną osobę jest bardzo obciążające fizycznie, jak i psychicznie, dlatego wydaje mi się, że ważne są nie tylko działania interwencyjne w rodzinach dotkniętych tym problemem, ale również prewencyjne, przez co rozumiem chociażby wspieranie rodziny w procesie zmiany (zapobieganie negatywnym skutkom od etapu pomysłu aż po jego wykonanie)" (E.9).

Badani eksperci zgodnie uważali, że szkoła powinna wspierać uczniów z rodzin migracyjnych. Szkoła jest, zdaniem badanych ekspertów, bardzo często pierwszym miejscem, gdzie rodzic lub dziecko może zasygnalizować problem i poprosić o pomoc. „Pomoc ze strony szkoły jako instytucji jest udzielana tylko $\mathrm{w}$ ramach dobrowolnej zgody rodziny $\mathrm{i} w$ takim zakresie, na jaki obie strony przystaną" (E.4). Poza wsparciem emocjonalnym szkoła może pomóc w zorganizowaniu opieki dla dziecka, które pozostaje pod opieką jednego z rodziców lub innych upoważnionych członków rodziny. Formy pomocy

\footnotetext{
${ }^{2}$ Kwestia przygotowania młodzieży do rozłąki emigracyjnej została poruszona także przez Annę Dąbrowską (2016).
} 
udzielanej uczniom, których rodzice wyjechali do pracy za granicę, zostały zanalizowane w badaniach Ministerstwa Edukacji Narodowej (zob. Ostrowska 2016). „Moja szkoła współpracuje z miejscową świetlicą socjoterapeutyczną i bardzo często korzystam z jej pomocy, aby wypełnić dziecku czas ciekawymi aktywnościami w bezpiecznym środowisku" (E.2). Jak wskazuje Wielisława Warzywoda-Kruszyńska $(2007,39)$, „Oddziaływanie na dobrostan dzieci i młodzieży może [...] okazać się znaczącym środkiem wspierającym wzmacnianie wśród nich potrzeb edukacyjnych, uznawanych za źródło sukcesu w nowoczesnym społeczeństwie".

Eksperci pytani o to, czy spotkali się z etykietą „eurosierota”, podkreślali negatywne nacechowanie tego terminu, o bardzo mocnej sile wyrazu ze względu na określenie „,sierota”. „Eurosierota zawiera w sobie jednocześnie potężną skalę możliwości, jaką daje przynależność do Unii Europejskiej, otwartość i ideę życia ponad podziałami, a zarazem wskazuje na przykre konsekwencje opuszczania rodziny - w poszukiwaniu lepszego, wydawałoby się, życia" (E.9). Zwracali uwagę na to, by ostrożnie posługiwać się stygmatyzującym terminem „eurosieroctwo”. „Również wśród grona nauczycielskiego unika się określenia - eurosierota, właśnie po to, by nie etykietować ucznia” (E.2).

Zdaniem ekspertów, problematyka funkcjonowania młodzieży pochodzącej z rodzin migracyjnych nie jest wystarczająco często poruszana podczas rozmów nauczycieli, rad pedagogicznych oraz różnego rodzaju szkoleń dla osób kierujących ofertę pomocową do rodzin migracyjnych. Ze względu na częstą obecność wyjazdów zagranicznych wiążących się z nieobecnością rodzica/rodziców szczególnie w mniejszych miejscowościach negatywne konsekwencje rozłąki są często bagatelizowane także przez osoby pracujące z rodzinami. „Zdecydowanie nie, nigdy nie spotkałam się ze ofertą szkolenia o podobnej tematyce. [...] Problem bywa umniejszany, zwłaszcza w miejscu, gdzie pracuję. Jest to mała miejscowość wiejska, z której ludzie często wyjeżdżają na dłuższe i krótsze okresy. Najpowszechniejszym kierunkiem wyjazdów jest Wielka Brytania, ale także Niemcy i Holandia. Dorośli przyjmują postawę: tak musi być, bo w kraju jest źle, a w rozmowach z dziećmi często słyszę echa ich słów" (E.9).

Eksperci zgadzali się, że problematyka funkcjonowania rodzin migracyjnych jest szczególnie ważna i aktualna, a wciąż rzadko poruszana. Upowszechnieniu problemów nie sprzyja współczesne podejście do nich, prezentowane przez jednostki borykające się z nimi, ale także przez ekspertów, dla których niejednokrotnie „Problemy stają się nieodłączną częścią codziennej egzystencji; jeśli są, trzeba je zdefiniować - nie po to, aby je rozwiązać, ale by z nimi żyć" (Oliwa-Ciesielska 2018, 91). Pedagodzy i psycholodzy zaznaczali, że w szkołach, w których pracują, w każdej klasie jest przynajmniej jeden uczeń z rodziny migracyjnej. Biorąc pod uwagę wszystkich ekspertów, 
problematyką funkcjonowania rodzin migracyjnych najczęściej zajmowali się pracownicy szkół, tacy jak pedagodzy i psycholodzy.

Przeprowadzone badania wskazują, że ich uczestnicy nie czują się odpowiednio przygotowani do pracy z członkami rodzin migracyjnych. Kierując ofertę pomocową do rodzin migracyjnych, opierali się na własnych pomysłach pracy. Nie stosowali żadnego specjalistycznego i programowego oddziaływania. Sytuacja młodzieży dorastającej w rodzinach migracyjnych wiążąca się z procesem adaptacji do nowych warunków budziła skojarzenia z procesem żałoby i rozwodu. Badania wskazują, że często podczas kierowania oferty pomocowej do rodziny migracyjnej konieczna jest współpraca międzyinstytucjonalna. Poniższa wypowiedź jest przykładem jednej z wielu świadczących o podejmowaniu współpracy między psychologami, pedagogami, pracownikami socjalnymi i kuratorami „Współpracuję z przedstawicielami różnych instytucji m.in. pracownikami MOPS-u, z kuratorem sądowym, pracownikami poradni psychologiczno-pedagogicznej, dzięki temu monitoruję sytuację rodzinną ucznia, mogę wspierać dziecko i jego rodzinę" (E.2). Jak wskazuje Danilewicz, „konsekwencje migracji zagranicznych stają się coraz większym wyzwaniem dla polityki społecznej państwa oraz pracy socjalnej” $(2014,119)$.

Niezależnie od podejmowanych środków zaradczych wiele konsekwencji rozłąki jest nieuniknionych. Ważnym aspektem prowadzonych badań jest w tym względzie odniesienie do procesu przejmowania przez dorastające dzieci migrantów roli człowieka dorosłego, co sprawia, że dziecko $z$ rodziny migracyjnej ma problemy i zmartwienia, które w okresie rozwojowym, w którym aktualnie się znajduje, normatywnie nie występują. Samodzielność i identyfikowana dojrzałość w funkcjonowaniu dziecka nie tylko zwalnia innych z obowiązku wsparcia, ale też powoduje dodatkowe obciążanie go problemami innych. Dla młodzieży mieszkającej z pozostającym w kraju rodzicem charakterystyczne jest poczucie zobowiązania do spędzania swojego wolnego czasu z rodzicem, który niejednokrotnie zaspokaja wówczas własną potrzebę uwagi innych, ale także otrzymuje od dziecka różnorodne wsparcie - zarówno emocjonalne, jak i instrumentalne. Ponadto porównywanie swojej sytuacji, obowiązków i czasu wolnego do tego, którym dysponowali rówieśnicy pochodzący z rodzin niemigracyjnych, jest dla dzieci migrantów konfrontującym doświadczeniem, które potęguje poczucie utraty i przeciążenia.

$* * *$

Wyjazdy zagraniczne niezmiennie są przedmiotem wielu dyskursów, które toczą się nie tylko w ramach naukowych ustaleń. Debata publiczna dotycząca problemu „eurosieroctwa” sprawia, że wiele osób uważa, iż ma prawo oceniać słuszność cudzej decyzji o emigracji. Oceny te, nie zawsze adekwatne do sy- 
tuacji, są komunikowane przez wiele podmiotów życia społecznego. Wśród nich są także instytucje edukacyjne i mimo że - jak wynika z prowadzonych przeze mnie badań z dziećmi emigrantów - nie doświadczyły one bezpośrednio stygmatyzacji ze strony nauczycieli, to wiele z nich było przekonanych, że przez tzw. „eurosieroctwo" są przez nauczycieli oceniane jako gorsze, stanowiące zagrożenie dla młodzieży z rodzin niemigracyjnych w związku z nadmierną, zdaniem nauczycieli, wolnością i brakiem kontroli. Bez względu na analizowane tło, według ekspertów, poruszanie problematyki dzieci doświadczających migracji rodziców odbywa się często w atmosferze skandalu. Stygmatyzujące zachowania ze strony otoczenia społecznego są dla młodzieży dodatkowym - poza samą rozłąką - bardzo trudnym doświadczeniem. Określenie „eurosieroctwo” jest rodzajem uznania kosztów i strat w związ$\mathrm{ku} \mathrm{z}$ wychowywaniem się $\mathrm{w}$ rodzinie migracyjnej. Przeprowadzone przeze mnie badania miały między innymi ukazać różne perspektywy spojrzenia na problem rodzin migracyjnych. Wyniki wskazują, że szczególnie pedagodzy i psycholodzy szkolni zauważają szereg trudności pojawiających się w związ$\mathrm{ku} \mathrm{z}$ dorastaniem uczniów $\mathrm{w}$ rodzinach migracyjnych. Zdaniem ekspertów, dziecko wychowujące się w rodzinie migracyjnej przede wszystkim zmaga się z permanentną tęsknotą za rodzicem. Osoby zawodowo pracujące z dziećmi i młodzieżą z rodzin migracyjnych dostrzegają, że nastolatek odczuwający tęsknotę za rodzicem przebywającym na emigracji zarobkowej, doświadczający odrzucenia, samotności, braku zrozumienia, często ucieka w wirtualny świat. Eksperci sugerowali, że warto zmianę w życiu całej rodziny przeprowadzać $\mathrm{z}$ dodatkowym wsparciem specjalisty (np. pracownika socjalnego). Ponadto zgadzali się, że problematyka funkcjonowania rodzin migracyjnych jest szczególnie ważna i aktualna, a wciąż rzadko poruszana. Przeprowadzone badania wskazują także, że eksperci nie czują się odpowiednio przygotowani do pracy z członkami rodzin migracyjnych i podają między innymi małą liczbę szkoleń dotyczących tej problematyki.

\section{THE ISSUE OF „EUROPEAN ORPHANHOOD” IN THE OPINION OF EXPERTS HELPING FAMILIES OF ECONOMIC MIGRANTS. SOCIAL WORK AND PSYCHOLOGICAL SUPPORT IN THE EXPERIENCES OF MIGRATION SEPARATION}

\section{SUMMARY}

Migration has become a fixed point in the way the lives of families experiencing separation are organized. In the study I used interviews with experts - representatives 
of assisstance professions who also dealt with migrant families. Through my detailed research, I tried to present history of life of people whose daily life is determined by separation and the "European orphan" stigma. The aim of the study was to break the „European orphan" stereotype and to look at the matter without judgement, and to show the perspective of those who are often talked about but rarely heard. Special media coverage informing about „European orphanhood” are fulfilled with stereotypes, generalisations and exaggerations which simply stigmatize and create negative image of children and teenagers growing up in migrant families. In the analysis „European orphanhood" is treated as a lack of a parent / parents due to economic migration after Poland joined the European Union.

Keywords: ,european orphanhood”, migration family, separation, adolescents, social work, social problem.

Słowa kluczowe: ,eurosieroctwo”, rodzina migracyjna, rozłąka, adolescencja, praca socjalna, problem społeczny.

\section{BIBLIOGRAFIA}

Baranowski, Paweł, et al. 2016. Wyjechać czy zostać? Determinanty zamiarów emigracji zarobkowej z Polski, Gospodarka Narodowa, 284(4), 69-89.

Chmielewska, Iza i Adam Panuciak i Paweł Strzelecki. 2019. Polacy pracujacy za granica w 2018 r. Raport z badania, Warszawa: Departament Statystyki.

Danilewicz, Wioleta. 2014. Nowe wyzwania dla pracy socjalnej wynikające z migracji zagranicznych. W: Praca socjalna z dziećmi, młodzieża i rodzina, red. Marzena Ruszkowska i Mikołaj Winiarski, 119-132. Warszawa: Centrum Rozwoju Zasobów Ludzkich.

Dąbrowska, Anna. 2016. Rodzina migracyjna w przestrzeni życiowej dorastajacych. Holistyczny model wsparcia. Warszawa: Wydawnictwo Naukowe PWN.

Duszczyk, Maciej i Jakub Wiśniewski. 2007. Analiza społeczno-demograficzna migracji zarobkowej Polaków do państw EOG po 1 maja 2004 roku. Warszawa: Instytut Spraw Publicznych.

Galasińska, Aleksandra i Anna Horolets. 2010. Migracja jako wielka narracja w zderzeniu z „opowieściami emigranckimi”: przypadek dyskusji o emigracji do Wielkiej Brytanii na forum internetowym. W: Migracje Polaków w Unii Europejskiej po 1 maja 2004 roku. Analiza psychologiczno-pedagogiczna, red. Halina Grzymała-Moszczyńska i Anna Kwiatkowska i Joanna Roszak, 55-69. Kraków: NOMOS.

Główny Urząd Statystyczny. 2019. Informacja o rozmiarach i kierunkach czasowej emigracji z Polski w latach 2004-2018. Dostęp 10.07.2020 r.

https://stat.gov.pl/obszary-tematyczne/ludnosc/migracje-zagraniczne-ludnosci/informacja-orozmiarach-i-kierunkach-czasowej-emigracji-z-polski-w-latach-2004-2018,2,12.html

Goleński, Wojciech. 2016. Społeczne skutki zagranicznych migracji zarobkowych z terenu województwa opolskiego dla dzieci emigrantów pozostających w Polsce, Studia Ekonomiczne. Zeszyty Naukowe Uniwersytetu Ekonomicznego w Katowicach, (290), 211-222.

Horolets, Anna i Magdalena Lesińska i Marek Okólski. 2019. Stan badań nad migracjami w Polsce na przełomie wieków. Próba diagnozy, Studia Migracyjne - Przeglad Polonijny, 172(2), 7-42. DOI: 10.4467/25444972SMPP.19.013.10839

Kaczmarczyk, Paweł i Marek Okólski. 2008. Polityka migracyjna jako instrument promocji zatrudnienia i ograniczania bezrobocia. Warszawa: Ośrodek Badań nad Migracjami. 
Kaczmarczyk, Paweł i Joanna Tyrowicz. 2007. Wspótczesne procesy migracyjne w Polsce a aktywność organizacji pozarzadowych $w$ obszarach powiazanych z rynkiem pracy. Warszawa: Fundacja Inicjatyw Społeczno-Ekonomicznych. Dostęp: 15.06.2020. https://fise.org.pl/wp-content/ uploads/2018/09/PKaczmarczyk_JTyrowicz_migracje.pdf

Kawczyńska-Butrym, Zofia. 2009. Migracje. Wybrane zagadnienia. Lublin: Wydawnictwo UMCS.

Kawczyńska-Butrym, Zofia i Marzena Kruk. 2015. Wsparcie społeczne dla rodzin migracyjnych w Polsce. W: Rodzina wobec wyzwań współczesności, red. Iwona Taranowicz i Stella Grotowska, 205-216. Wrocław: Oficyna Wydawnicza ARBORETUM.

Kozielska, Joanna. 2014. Poakcesyjne migracje zarobkowe. Kontekst teoretyczny empiryczny. Wsparcie spoleczne. Poznań: Wydawnictwo Naukowe UAM.

Krzyżowski, Łukasz i Janusz Mucha. 2012. Opieka społeczna w migranckich sieciach rodzinnych. Polscy migranci w Islandii i ich starzy rodzice w Polsce. Kultura i Społeczeństwo, 56(1), 191-217. DOI: $10.2478 / \mathrm{v} 10276-012-0010-8$

Oliwa-Ciesielska, Monika. 2018. Praca socjalna w obszarze wykluczenia społecznego. W: Wielość spojrzeń na istote pracy socjalnej w teorii i praktyce, red. Anna Kotlarska-Michalska, 75-92. Poznań: Wydawnictwo Wydziału Nauk Społecznych UAM.

Ostrowska, Krystyna. 2016. O sytuacji dzieci, których rodzice wyjechali za granice $w$ celach zarobkowych. Raport 2016. Warszawa: Ośrodek Rozwoju Edukacji. Dostęp: 16.06.2020. https:// www.ore.edu.pl/2017/12/o-sytuacji-dzieci-ktorych-rodzice-wyjechali-za-granice-w-celachzarobkowych-raport-2016/

Walczak, Bartłomiej. 2008. Migracje rodzicielskie. W: Zeszyty metodyczne. Szkoła wobec mobilności zawodowej rodziców i opiekunów. Niezbędnik nauczyciela, red. Ewa Kozdrowicz i Bartłomiej Walczak, 7-20. Warszawa: Centrum Metodyczne Pomocy Psychologiczno-Pedagogicznej.

Warzywoda-Kruszyńska, Wielisława. 2007. Przeciwdziałanie ubóstwu dzieci. Polityka Społeczna, (8), 38-44.

Natasza Doiczman-Łoboda - dr, socjolog i psycholog, adiunkt w Zakładzie Badań Problemów Społecznych i Pracy Socjalnej Wydziału Socjologii Uniwersytetu im. Adama Mickiewicza w Poznaniu. Autorka kilkunastu artykułów naukowych dotyczących problematyki psychospołecznej. Jej zainteresowania badawcze koncentrują się wokół sposobu funkcjonowania rodzin migracyjnych, postrzegania czasu, samotności i rozłąki oraz sieroctwa społecznego. natasza.doiczman@ amu.edu.pl 